\title{
Seasonal nitrogen fixation and primary production in the Southwest Pacific: nanoplankton diazotrophy and transfer of nitrogen to picoplankton organisms
}

\author{
Nicole Garcia*, Patrick Raimbault, Valérie Sandroni
}

Laboratoire d'Océanographie et de Biogéochimie, Centre d'Océanologie de Marseille, CNRS, Université de la Méditerranée, 163 avenue de Luminy, case 901, 13288 Marseille cedex 9, France

\begin{abstract}
We applied a high-sensitivity dual isotopic tracer technique $\left({ }^{13} \mathrm{C}:{ }^{15} \mathrm{~N}\right)$ to measure $\mathrm{N}_{2}$ fixation and primary production in the total phytoplanktonic community and in 3 size fractions $(>10,<10$ and $<3 \mu \mathrm{m}$ ) in oceanic waters around New Caledonia (Southwest Pacific). This region seemed to be favourable for diazotrophy, which is observed at significant rates over the year throughout both oceanic and lagoonal habitats. Nitrogen-fixation rates were high, but presented some spatial heterogeneity and high seasonal variability. Large phytoplankton $(>10 \mu \mathrm{m}$, i.e. Trichodesmium) often fixed the bulk of available nitrogen at very high rates (up to $1.8 \mathrm{nmol} \mathrm{l}^{-1} \mathrm{~h}^{-1}$ ). Elevated ${ }^{15} \mathrm{~N}_{2}$ accumulation (up to $0.83 \mathrm{nmol} \mathrm{l}^{-1} \mathrm{~h}^{-1}$ ) was always observed in the $<10 \mu \mathrm{m}$ fraction, representing a mean of $31 \pm 20 \%$ of total $\mathrm{N}_{2}$ fixation, up to $92 \%$ in the lagoon and $98 \%$ in the oceanic region. Direct fixation was detected in the $<10 \mu \mathrm{m}$ fraction during the day as well as during the night in the New Caledonia lagoon, indicating that unicellular nanoplanktonic cyanobacteria could be a significant source of new nitrogen. Some accumulation of ${ }^{15} \mathrm{~N}_{2}$ was also detectable in the $<3 \mu \mathrm{m}$ fraction, especially in surface samples. The rates of this nitrogen accumulation were generally very low $\left(<0.17 \mathrm{nmol} \mathrm{l}^{-1} \mathrm{~h}^{-1}\right)$, representing $\sim 10 \%$ of total fixation. However, in August 2002, this ${ }^{15} \mathrm{~N}$ accumulation in the $<3 \mu \mathrm{m}$ fraction contributed nearly $50 \%$ of the total nitrogen fixation. However, with the post-size-fractionation experiments it was not possible to distinguish direct $\mathrm{N}_{2}$ fixation from picoplanktonic assimilation of organic compounds released by large cyanobacteria. Nevertheless, the results demonstrate a close coupling between larger diazotrophs and picoplanktonic populations, and show that new nitrogen could rapidly be provided for the pelagic microbial food web.
\end{abstract}

KEY WORDS: Nitrogen fixation · Nanoplankton $\cdot$ Picoplankton $\cdot$ New Caledonia

Resale or republication not permitted without written consent of the publisher

\section{INTRODUCTION}

Nitrogen is generally accepted as the most common nutrient limiting phytoplanktonic primary production throughout much of the world's oceanic surface waters. Because of this, biological fixation of gaseous nitrogen (an unlimited source from the atmosphere), also called diazotrophy, has gained recognition as an important process in supporting oceanic primary production (Lipschultz \& Owens 1996, Capone et al. 1998). Due to their ability to fix $\mathrm{N}$, the cyanobacteria can contribute substantially to the input of new nitrogen into nutrient-poor environments. This nitrogen pool can represent a potentially important nitrogen source for other organisms in the pelagic food web. The diazotrophy process can be carried out by a number of different types of prokaryotic organisms, but in the ocean, the process appears to be supported for the most part photoautotrophically by cyanobacteria in sunlit surface waters (Paerl 1990). The majority of studies on $\mathrm{N}_{2}$ fixation in open ocean waters have focused on rate measurements of the colonial forms of Trichodesmium spp. The large size classes (Trichodesmium and diatoms containing endosymbiotic Richelia) appear to be the 
dominant diazotrophs in tropical and sub-tropical waters (Zehr \& Capone 1996, Capone et al. 1997, 2005; Mulholland \& Capone 2000) and are thought to be responsible for the bulk of marine $\mathrm{N}_{2}$ fixation. Recently, however, unicellular diazotrophic cyanobacteria and bacterioplankton have been found in the nanoplankton community of the North Pacific central gyre (Zehr et al. 2001). A range of molecular and isotopic evidence suggests that these unicells could support a significant fraction of new production in oligotrophic waters (Montoya et al. 2004), even if low numeric abundance of these organisms poses challenges for quantifying their nitrogen fixation activity.

In the present study, we applied the ${ }^{15} \mathrm{~N}_{2}$-tracer method, which made it possible to measure the rate of $\mathrm{N}_{2}$ fixation directly on non-concentrated natural samples and to follow the fate of the new nitrogen into different components of the planktonic food web. We provide evidence for the existence of nanoplanktonic diazotrophic cyanobacteria $(<10 \mu \mathrm{m})$ in the surrounding waters of New Caledonia, and noted a rapid and significant accumulation of newly fixed nitrogen in the picoplanktonic fraction $(<3 \mu \mathrm{m})$.

\section{MATERIALS AND METHODS}

Experiments were performed around New Caledonia, Southwest Pacific (Fig. 1), between January 2002 and October 2003, during 6 Diapalis cruises on the 'Institut pour la Recherche et le Développement' (IRD) ship 'l'Alis', and in the Noumea lagoon during October 2005 (Table 1). Several stations representing different ecosystems (lagoon, open bay, open ocean) were sampled. Specifically, our study was concerned with 4 locations where size-fractionation experiments were performed: the 'Baie du Santal' (open bay, 208' S, $\left.167^{\circ} 1^{\prime} \mathrm{E}\right)$, the 'Chenal des Loyautés' (open ocean, $21^{\circ} 5^{\prime} \mathrm{S}, 167^{\circ} \mathrm{E}$ ), the 'Nord Ouvéa' (open ocean,

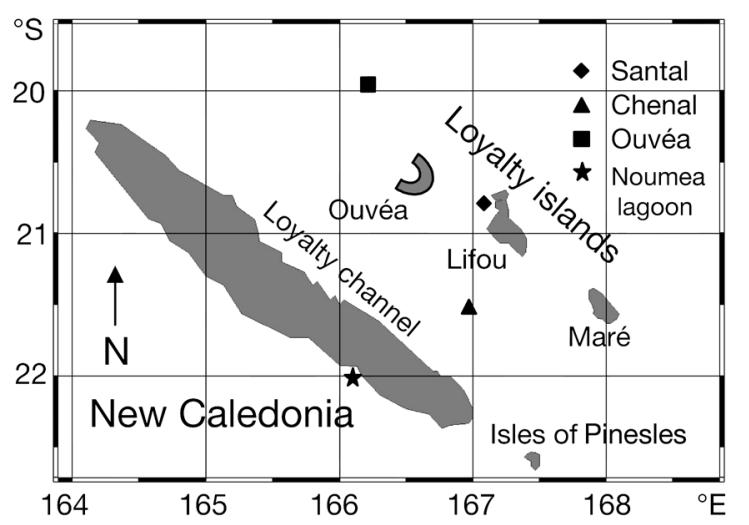

Fig. 1. Study area with sampling locations
Table 1. Dates of the Diapalis cruises and Noumea Lagoon experiments

\begin{tabular}{|ll|}
\hline Cruise & \multicolumn{1}{c|}{ Date } \\
\hline Diapalis 3 & 15-22 Jan 2002 \\
Diapalis 4 & 3-8 Apr 2002 \\
Diapalis 5 & 21-28 May 2002 \\
Diapalis 6 & $5-11$ Aug 2002 \\
Diapalis 7 & 3-12 Feb 2003 \\
Diapalis 9 & $9-16$ Oct 2003 \\
Noumea Lagoon & 20-28 Oct 2005 \\
\hline
\end{tabular}

$\left.20^{\circ} 00^{\prime} \mathrm{S}, 166^{\circ} 23^{\prime} \mathrm{E}\right)$ and the Noumea lagoon $\left(22^{\circ} 20^{\prime} \mathrm{S}\right.$, $\left.16^{\circ} 30^{\prime} \mathrm{E}\right)$.

During Diapalis cruises, water samples were collected using a CTD-rosette $(12 \times 81$ Niskin bottles $)$ at 7 different depths $(0,10,20,30,40,80$ and $100 \mathrm{~m})$. In the lagoon, samples were taken between 0 and $20 \mathrm{~m}$ depth. Nitrogen fixation rates were determined using a highly sensitive ${ }^{15} \mathrm{~N}_{2}$-tracer method (Montoya et al. 1996), in parallel with primary production by the dual ${ }^{13} \mathrm{C}:{ }^{15} \mathrm{~N}$-labelling technique.

Polycarbonate Nalgene flasks $(1200 \mathrm{ml})$ were filled directly from the Niskin bottles without any treatment, except during lagoon experiments, in which some samples were immediately filtered (by gravity) on a $10 \mu \mathrm{m}$ polycarbonate membrane to eliminate large diazotrophs. Thus, in these pre-fractionated samples, only the nanoplanktonic fraction was incubated, isolated from the large phytoplankton, to test whether any $\mathrm{N}_{2}$ is fixed by this nanoplanktonic fraction. Subsequent experimental and analytical procedures were the same for all samples. In each bottle, ${ }^{13} \mathrm{C}$-labelled bicarbonate sodium $\left(\mathrm{NaH}^{13} \mathrm{CO}_{3}\right.$ : 6 g $250 \mathrm{ml}^{-1}$ deionised water, 99 atomic $\%{ }^{13} \mathrm{C}_{\text {; }}$ Eurisotop) was added in order to obtain a $10 \%$ final enrichment ( $1 \mathrm{ml} 1200 \mathrm{ml}^{-1}$ seawater). The ${ }^{15} \mathrm{~N}_{2}$ gas (99 atomic $\%{ }^{15} \mathrm{~N}$, Eurisotop) was introduced to the bottle through a gas-tight septum (2 $\mathrm{ml}$ of gas $1200 \mathrm{ml}^{-1}$ seawater), to achieve a tracer addition of $\sim 10 \%$. We added a fixed quantity of ${ }^{15} \mathrm{~N}_{2}$ gas and calculated the enrichment of each bottle on the basis of its volume and the solubility of $\mathrm{N}_{2}$. We used the equations provided by Weiss (1970) to calculate the $\mathrm{N}_{2}$ initial concentration, assuming equilibrium with the overlying atmosphere. The ${ }^{15} \mathrm{~N}_{2}$ enrichment in the incubation bottles ranged between 11 and $14 \%$. The sample was carefully shaken to allow equilibration between ${ }^{15} \mathrm{~N}_{2}$ and natural $\mathrm{N}_{2}$. After ${ }^{13} \mathrm{C}$ and ${ }^{15} \mathrm{~N}$ addition, the samples were incubated on a drifting rig at the same depth from which they were collected, from sunrise to sunset (12 \pm $1 \mathrm{~h}$ ). Night incubations were performed on the $>$ GF/F (see explanation in following paragraph) fraction during Diapalis 5 and on the $>$ GF/F and $<10 \mu \mathrm{m}$ pre-fractionated fractions during lagoon experiments. 
After incubation, pre-fractionated samples were immediately filtered on a pre-combusted $(24 \mathrm{~h}$ at $450^{\circ} \mathrm{C}$ ), $25 \mathrm{~mm}$ Whatman $\mathrm{GF} / \mathrm{F}$ filter. Size fractionation was performed on all total samples and allowed us to investigate 3 phytoplanktonic fractions in addition to the total phytoplankton community: (1) the $>10 \mu \mathrm{m}$ fraction commonly represented by diazotrophs of the genus Trichodesmium, (2) the $<10 \mu \mathrm{m}$ size fraction corresponding to nanoplankton (Malone 1980) and (3) the $<3 \mu \mathrm{m}$ size fraction, defined here as picoplankton (Stockner \& Antia 1986). In these definitions, the nanoplankton also includes the picoplankton. First, $600 \mathrm{ml}$ were directly filtered under a gentle vacuum (100 mm $\mathrm{Hg}$ ) on a pre-combusted $\left(24 \mathrm{~h}\right.$ at $\left.450^{\circ} \mathrm{C}\right), 25 \mathrm{~mm}$ Whatman GF/F filter; this sample is called the '>GF/F fraction'. The remaining $600 \mathrm{ml}$ were treated either as the isolated $<10 \mu \mathrm{m}$ fraction or as the collected $>3 \mu \mathrm{m}$ fraction as follows: (1) To isolate the $<10 \mu \mathrm{m}$ fraction and to remove Trichodesmium and large phytoplankton, samples were gravity pre-filtered on a $10 \mu \mathrm{m}$ pore-size polycarbonate filter; $<10 \mu \mathrm{m}$ filtrates were then collected on a pre-combusted $\left(24 \mathrm{~h}\right.$ at $\left.450^{\circ} \mathrm{C}\right), 25 \mathrm{~mm}$ Whatman GF/F filter. The nitrogen fixation due to the large phytoplankton $(>10 \mu \mathrm{m})$ was obtained from the difference between nitrogen fixation of the $>\mathrm{GF} / \mathrm{F}$ fraction and the $<10 \mu \mathrm{m}$ fraction of the same incubated samples. (2) To collect the $>3 \mu \mathrm{m}$ fraction, samples were filtered on $3 \mu \mathrm{m}$ pore-size silver pre-combusted $\left(24 \mathrm{~h}\right.$ at $\left.450^{\circ} \mathrm{C}\right)$ Poretics filters. Nitrogen fixation in the $<3 \mu \mathrm{m}$ fraction was obtained from the difference between nitrogen fixation of the $>$ GF/F fraction and the $<3 \mu \mathrm{m}$ fraction of the same incubated samples.

All filters were dried in a $60^{\circ} \mathrm{C}$ oven for $24 \mathrm{~h}$ and analysed as soon as possible after the cruise. The dual isotopic enrichment analysis was performed on an Integra-CN PDZ Europa mass spectrometer, calibrated with glycine references every batch of 10 to 15 samples. The accuracy of our analytical system was also regularly verified using reference materials from the International Atomic Energy Agency (AIEA, Analytical Quality Control Services). The mean values of the natural atomic percent (at.\%) of ${ }^{15} \mathrm{~N}$ and total nitrogen for glycine standards containing 0.2 to $10 \mu \mathrm{mol} \mathrm{N}$, as well as results from standard references, are given in Table 2 . These data indicated that the analysing system is highly stable and accurate. The mean at. $\%{ }^{15} \mathrm{~N}$ did not vary between samples from 0.5 to $10 \mu \mathrm{mol} \mathrm{N}$. ${ }^{15} \mathrm{~N}$ enrichment appeared slightly underestimated at the lowest nitrogen mass $(0.2 \mu \mathrm{mol})$. Nevertheless, this variation $(<0.001 \%)$ is orders of magnitude smaller than the enrichment measured during the experiments in the present study, ranging from 0.02 to $0.70 \%$. The low background of the system allows safe analysis of samples containing low nitrogen concentrations ( 0.2 to $0.5 \mu \mathrm{mol})$, values often observed in surface olig- otrophic waters. The ${ }^{15} \mathrm{~N}$ isotope enrichment of a sample is reported in terms of at. \% excess of ${ }^{15} \mathrm{~N}$ over time in reference to the at. $\%{ }^{15} \mathrm{~N}$ in a non-enriched sample originating from the same phytoplankton population. Therefore, it is necessary to know the value of Time 0 enrichment is necessary; this is determined using samples (same volume as incubated sample) that are filtered immediately after isotope addition. The Time 0 value, established using 8 samples, was $0.3663 \pm$ $0.007 \%$. Although the Time 0 enrichment was close to natural abundance in the atmosphere $(0.3663 \%)$, indicating no residual tracer on the filter after filtration and drying, we considered results with ${ }^{15} \mathrm{~N}$ enrichments $>0.014 \%$ (2 times the standard deviation obtained with Time 0 samples) to be significant.

Nitrogen fixation rates $\left(\rho_{\mathrm{N} 2}\right)$ can be directly calculated from ${ }^{15} \mathrm{~N}$-excess enrichment found in the GF/F and $>10 \mu \mathrm{m}$ fractions, as well as in the $>10 \mu \mathrm{m}$ prefractionated fraction. But, as we cannot certify that ${ }^{15} \mathrm{~N}$ excess enrichment in the smallest fractions $(<10 \mu \mathrm{m})$ was nitrogen fixation and not trophic transfer, calculated rates are designated nitrogen accumulation $\left(\rho_{\mathrm{acN} 2}\right)$.

$\rho_{\mathrm{N} 2}$ and $\rho_{\mathrm{acN} 2}$ are calculated according to the following equation (Dugdale \& Wilkerson 1986):

$$
\rho_{\mathrm{N} 2}=\rho_{\mathrm{acN} 2}=\left[\left(R_{\mathrm{PN}} / R_{\mathrm{n} 2}\right) / T\right] \times \mathrm{PN}
$$

Table 2. Evolution of ${ }^{15} \mathrm{~N}$ natural enrichment of glycine, given as ${ }^{15} \mathrm{~N}$ (atomic \%, at. \%) and $\delta^{15} \mathrm{~N}(\%)$, as a function of quantity of nitrogen analysed, calibrated against International Atomic Energy Agency (IAEA) reference materials

\begin{tabular}{|lccc|}
\hline $\begin{array}{l}\text { Glycine } \\
\text { samples }(\mu \mathrm{mol})\end{array}$ & $\begin{array}{c}\text { Particulate nitrogen } \\
(\mu \mathrm{mol})\end{array}$ & $\begin{array}{c}{ }^{15} \mathrm{~N} \\
(\text { at. } \%)\end{array}$ & $\begin{array}{c}\delta^{15} \mathrm{~N} \\
(\%)\end{array}$ \\
\hline 0.2 & 0.21 & 0.3672 & 2.50 \\
0.2 & 0.21 & 0.3673 & 2.60 \\
0.5 & 0.51 & 0.3678 & 4.02 \\
0.5 & 0.53 & 0.3678 & 4.19 \\
1.0 & 1.02 & 0.3679 & 4.28 \\
1.0 & 1.04 & 0.3677 & 3.95 \\
2.0 & 2.03 & 0.3679 & 4.39 \\
2.0 & 2.10 & 0.3681 & 4.84 \\
2.5 & 2.58 & 0.3679 & 4.41 \\
2.5 & 2.53 & 0.3680 & 4.51 \\
5.0 & 5.07 & 0.3679 & 4.50 \\
5.0 & 5.20 & 0.3680 & 4.59 \\
7.5 & 7.04 & 0.3679 & 4.48 \\
7.5 & 7.52 & 0.3680 & 4.68 \\
10 & 9.79 & 0.3680 & 4.73 \\
10 & 10.15 & 0.3681 & 4.91 \\
Mean & & 0.3678 & 4.28 \\
Standard deviation & & 0.0003 & 0.28 \\
Reference materials & & & \\
Urea (IAEA 310A) & 5.23 & $47.3 \pm 0.27$ & \\
$\delta^{15} \mathrm{~N}=47 \%$ o & & & \\
Urea (IAEA 310B) & 4.49 & $243 \pm 0.46$ & \\
$\delta^{15} \mathrm{~N}=244 \%$ o & & & \\
\hline
\end{tabular}


where PN corresponds to the final particulate nitrogen concentration and $T$ to the incubation period in hours. $R_{\mathrm{PN}}$ and $R_{\mathrm{n} 2}$ are the at. $\%{ }^{15} \mathrm{~N}$ excess enrichments in the particulate $\mathrm{N}_{2}$ and dissolved $\mathrm{N}_{2}$ pool, respectively. To facilitate comparison to literature data, ${ }^{15} \mathrm{~N}$ fixation

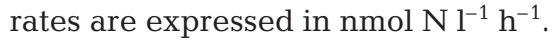

Under these experimental conditions, the detection limit for nitrogen fixation, calculated from significant enrichment $(0.38 \%)$ and particulate nitrogen $(0.2 \mu \mathrm{mol})$, is estimated with Eq. (1) to be $0.3 \mathrm{nmol} \mathrm{l}^{-1}$ $12 \mathrm{~h}^{-1}$. To test the reproducibility of the procedure, 3 profiles for $>$ GF/F nitrogen fixation (included in the results) were performed with triplicates during Diapalis 6 . The coefficient of variation for each set of 3 samples varied from 7 to $20 \%$.

Carbon fixation rates were calculated according to Slawyk \& Collos (1984), with a Time 0 enrichment of $1.113 \pm 0.005 \%(\mathrm{n}=8)$. This Time 0 value is a little higher than the natural abundance for phytoplankton (1.089), certainly due to some residual traces of ${ }^{13} \mathrm{C}$ tracer. It should be noted that ${ }^{13} \mathrm{C}$ enrichment of samples was less problematic than ${ }^{15} \mathrm{~N}$ enrichment, since inorganic carbon was assimilated by all phytoplankton, and excess values ranged from 0.3 to $3.6 \% .{ }^{13} \mathrm{C}$ fixation rates, i.e. primary production, are expressed in $\mu \mathrm{g} \mathrm{C}$ per litre per $12 \mathrm{~h}$.

Concentrations of free trichomes and colonies of Trichodesmium were determinated during Diapalis 7 and 9, by filtering 81 (the entire Niskin bottle) of seawater from the rosette casts onto a $10 \mu \mathrm{m}$ pore-size, $47 \mathrm{~mm}$ diameter Nuclepore filter. A $47 \mathrm{~mm}$ filter holder Gelman Sciences containing the filter was attached to the spigot of the Niskin bottle with tubing, and the water was filtered by gravity. The filter was then collected in a polyethylene flask filled with $20 \mathrm{ml}$ of $0.2 \mu \mathrm{m}$ filtered seawater and preserved with paraformaldehyde $(0.5 \%$ final concentration). Counts were made in the laboratory with a Zeiss optical microscope at $75 \times$ magnification.

\section{RESULTS}

Fig. 2 revealed the observed $\mathrm{N}_{2}$-fixation $\left(\rho_{\mathrm{N} 2}\right)$ rate profiles of the GF/F. $\rho_{\mathrm{N} 2}$ values were significant for all Diapalis cruises, ranging from 0.08 to $1.8 \mathrm{nmol} \mathrm{l}^{-1} \mathrm{~h}^{-1}$, with a maximum always observed in the surface layer ( 0 to $20 \mathrm{~m}$ ). The highest rates were found in February 2003 (Diapalis 7), with a maximum of $1.8 \mathrm{nmol} \mathrm{l}^{-1} \mathrm{~h}^{-1}$ at $20 \mathrm{~m}$.

The range of fixation rates varied according to the season. In April, May and August 2002, $\rho_{\mathrm{N} 2}$ did not exceed $0.42 \mathrm{nmol} \mathrm{l}^{-1} \mathrm{~h}^{-1}$ (Fig. 2a). Intermediate values (0.4 to $0.7 \mathrm{nmol} \mathrm{l}^{-1} \mathrm{~h}^{-1}$ ) characterised the Diapalis 9 cruise (October 2003), while the highest values (0.83 to $1.7 \mathrm{nmol} \mathrm{l}^{-1} \mathrm{~h}^{-1}$ ) were found in February 2003, for Dia- palis 7 (Fig. 2b). The night fixation rates, only measured during Diapalis 5, were not significant (Fig. 2a).

The $\mathrm{N}_{2}$-fixation rate in the $>10 \mu \mathrm{m}$ size fraction was generally dominant, ranging between 0.08 and $1.5 \mathrm{nmol} \mathrm{l}^{-1} \mathrm{~h}^{-1}$ (Fig. 3), the highest value being obtained during Diapalis 7 (February 2003). Diapalis 9 (October 2003) showed a unique pattern, with no $\mathrm{N}_{2}$ fixation rates measured in the $>10 \mu \mathrm{m}$ size fraction (Fig. 3d). ${ }^{15} \mathrm{~N}_{2}$ accumulation $\left(\rho_{\mathrm{acN} 2}\right)$ in the $<10 \mu \mathrm{m}$ size fraction showed different results according to the respective cruises. For Diapalis 4, 5 and 7 (Fig. 3a-c), rates $<0.4 \mathrm{nmol} \mathrm{l}^{-1} \mathrm{~h}^{-1}$ were observed along the water column. The Diapalis 9 cruise (Fig. 3d) presented the highest $\rho_{\text {acN2}}$ in the $<10 \mu \mathrm{m}$ size fraction, with a maximum of $0.75 \mathrm{nmol} \mathrm{l^{-1 }} \mathrm{h}^{-1}$ at the surface and around $0.4 \mathrm{nmol}^{-1} \mathrm{~h}^{-1}$ down to $40 \mathrm{~m}$. It should be noted that at depth (80 to $100 \mathrm{~m}), \rho_{\mathrm{acN} 2}$ in the $<10 \mu \mathrm{m}$ size fraction was always detected and significant. Results obtained from 7 successive lagoon experiments demonstrated the existence of intense nitrogen fixation in the $<10 \mu \mathrm{m}$ fraction (Fig. 4), even when previously isolated from the largest phytoplankton species. Day and night rates were similar, ranging from 0.33 to $0.7 \mathrm{nmol} \mathrm{l}^{-1} \mathrm{~h}^{-1}$ over the water column. It should be noted that, during the same experiments, nitrogen fixation in the $>10 \mu \mathrm{m}$ fraction was very low during the day $\left(<0.08 \mathrm{nmol} \mathrm{l}^{-1}\right.$ $\mathrm{h}^{-1}$ in mean) and close to 0 during the night, indicating low activity of large diazotrophs during these experiments.

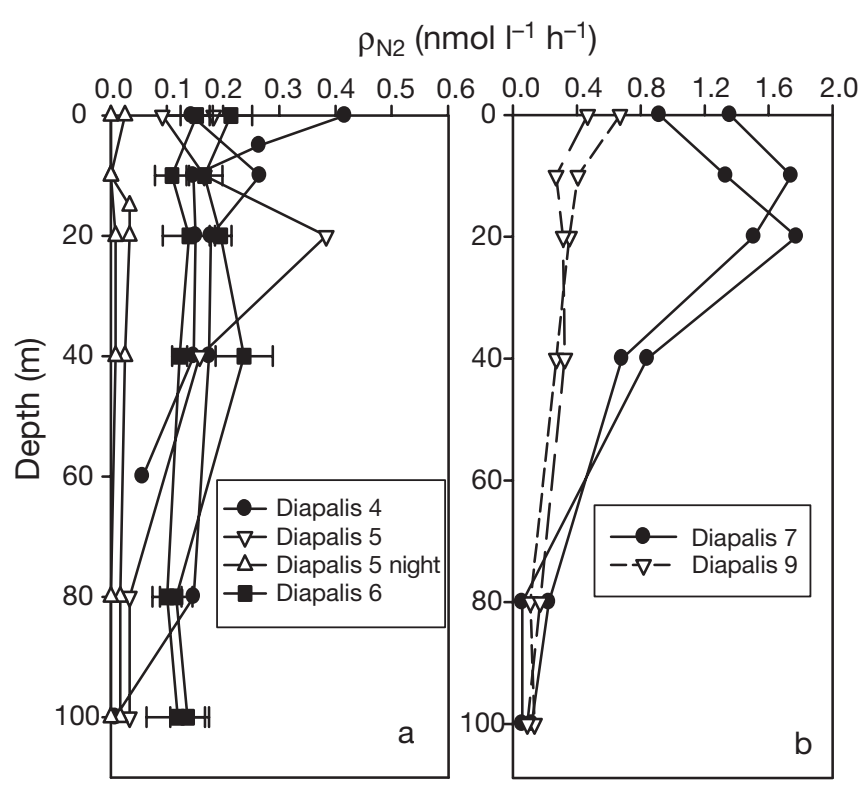

Fig. 2. Vertical profiles of nitrogen fixation $\left(\rho_{\mathrm{N} 2}\right)$ obtained at stations where size fractionation was performed: (a) cruises with rates $<0.4 \mathrm{nmol} \mathrm{l}^{-1} \mathrm{~h}^{-1}$ and (b) cruises with highest rates. Two night incubation profiles, obtained during the Diapalis 5 cruise, are included 


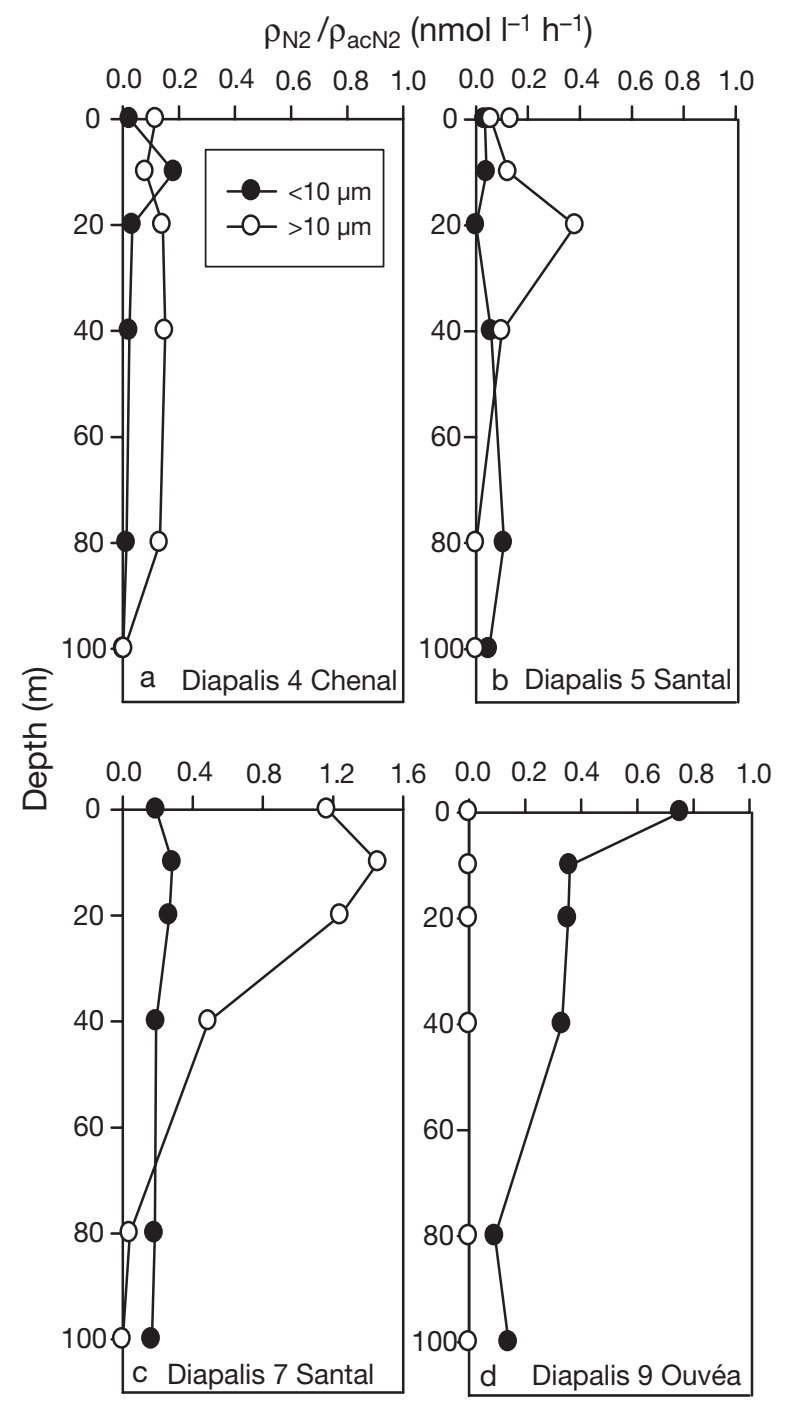

Fig. 3. Examples of vertical profiles of nitrogen fixation in the $>10 \mu \mathrm{m}\left(\rho_{\mathrm{N} 2}\right)$ and ${ }^{15} \mathrm{~N}_{2}$ accumulation $\left(\rho_{\mathrm{acN} 2}\right)$ in the $<10 \mu \mathrm{m}$ size fraction: (a) Diapalis 4 'Chenal des Loyautés' location, (b) Diapalis 5 'Baie du Santal' location, (c) Diapalis 7 'Baie du

Santal' location and (d) Diapalis 9 'Nord Ouvéa' location

In addition, we investigated the ${ }^{15} \mathrm{~N}$ enrichment within the picoplankton fraction $(<3 \mu \mathrm{m})$. Fixed nitrogen accumulation $\left(\rho_{\mathrm{acN} 2}\right)$ in the $<3 \mu \mathrm{m}$ size fraction (Fig. 5) was generally close to the detection limit. Meanwhile, significant $\rho_{\mathrm{acN} 2}$ values were measured at some depths of the vertical profile, principally at the surface during Diapalis 4 and 5, but were always $<0.08 \mathrm{nmol} \mathrm{l}^{-1} \mathrm{~h}^{-1}$.

During Diapalis 6, we observed $\rho_{\mathrm{acN} 2}$ values in the $<3 \mu \mathrm{m}$ size fraction equivalent to those in the $>3 \mu \mathrm{m}$ size fraction (Fig. 5c), with estimates commonly $>0.08 \mathrm{nmol} \mathrm{l}^{-1} \mathrm{~h}^{-1}$. During Diapalis 7 (Fig. 5d), when the highest total fixation rates were observed, significant $\rho_{\text {acN2 }}$ values were detected in the $<3 \mu \mathrm{m}$ size frac- tion, but only in subsurface samples (up to $0.17 \mathrm{nmol}^{-1}$ $\left.\mathrm{h}^{-1}\right)$.

Pooling all available data from Diapalis 3 to $7, \rho_{\mathrm{acN} 2}$ in the $<10 \mu \mathrm{m}$ fraction accounted for $31 \pm 20 \%$ of total nitrogen fixation and appeared to be more or less permanent and constant, while fixation in the greater fraction showed more substantial variation (Fig. 6a). In the same manner, no linear relationship was found between $\rho_{\mathrm{N} 2}$ in the $>3 \mu \mathrm{m}$ size fraction and $\rho_{\mathrm{acN} 2}$ in the $<3 \mu \mathrm{m}$ size fraction (Fig. $6 \mathrm{~b}$ ). Most of the time, high $\rho_{\mathrm{N} 2}$ values were measured in the $>3 \mu \mathrm{m}$ without ${ }^{15} \mathrm{~N}$ accumulation in the smaller fraction. But, in contrast, significant $\rho_{\mathrm{acN} 2}$ values were detected in the $<3 \mu \mathrm{m}$ size fraction $\left(>0.03 \mathrm{nmol} \mathrm{l^{-1 }} \mathrm{h}^{-1}\right)$, even when $\rho_{\mathrm{N} 2}$ in the largest size fraction was very low $\left(<0.17 \mathrm{nmol} \mathrm{l}^{-1} \mathrm{~h}^{-1}\right)$. In Fig. $6 \mathrm{~b}$, the 4 isolated points correspond to Diapalis 7 data, characterised by numerous Trichodesmium populations (500 to 700 trichomes $1^{-1}$ at the surface). During Diapalis 9, very high $\rho_{\mathrm{acN} 2}$ values were observed in the $<10 \mu \mathrm{m}$ fraction, while $\rho_{\mathrm{N} 2}$ in the largest fraction was insignificant (Fig. 6a). Similar results were found in the lagoon with pre-fractionated and post-fractionated samples; $\rho_{\mathrm{N} 2}$ was highly significant in the $<10 \mu \mathrm{m}$ fraction, but very low or undetectable in the largest size fraction.

Concurrently, a comparison of total primary production $\left({ }^{13} \mathrm{C}\right.$ assimilation) with primary production in the $<10$ and $<3 \mu \mathrm{m}$ size fractions showed they were both linearly related $\left(\mathrm{r}^{2}=0.95, \mathrm{n}=63\right.$ for the $<10 \mu \mathrm{m}$ size fraction; $\mathrm{r}^{2}=0.73, \mathrm{n}=36$ for the $<3 \mu \mathrm{m}$ size fraction).

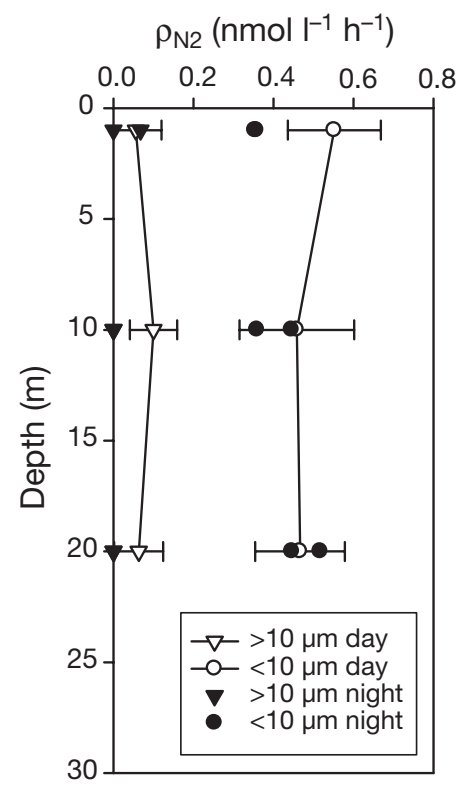

Fig. 4. Day and night lagoon vertical profiles of nitrogen fixation $\left(\rho_{\mathrm{N} 2}\right)$ in the $>10$ and pre-fractionated $<10 \mu \mathrm{m}$ fraction. Mean day rates and standard deviation were obtained from 7 experiments 


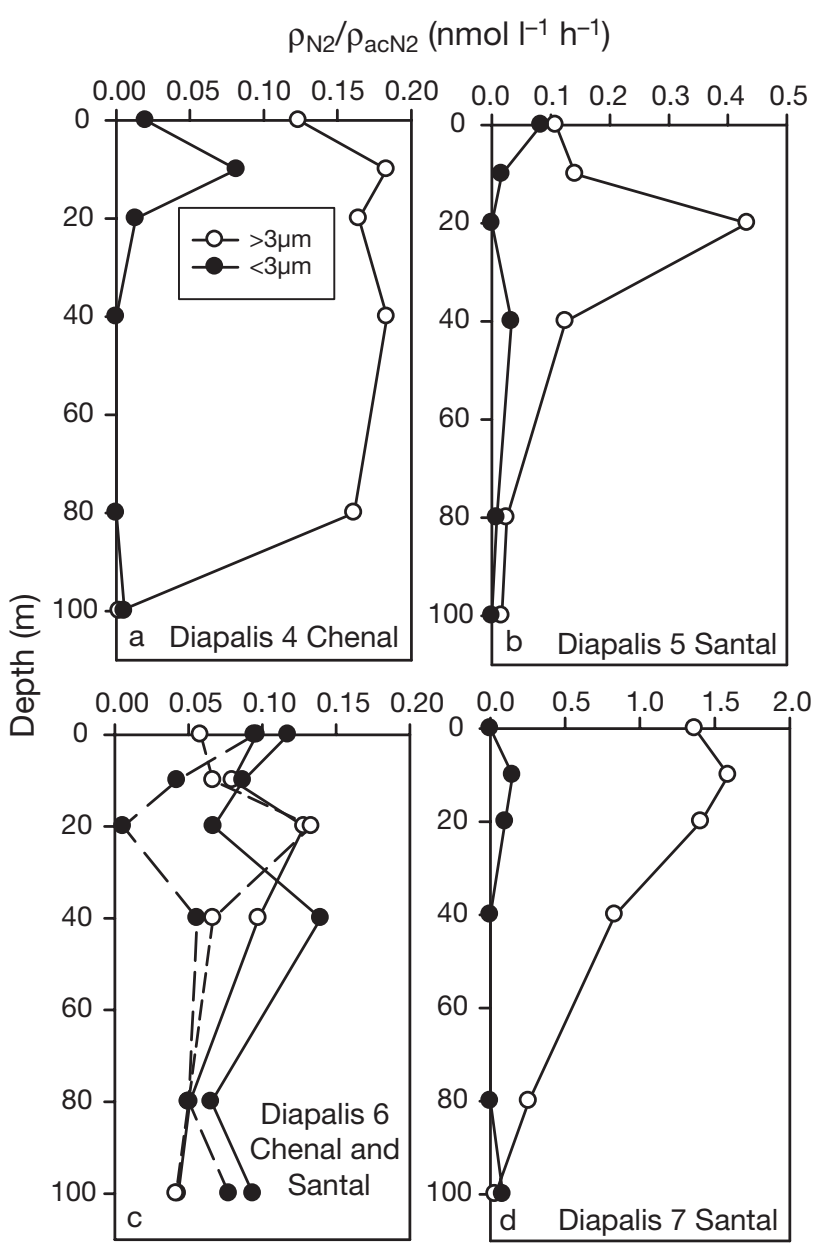

Fig. 5. Examples of vertical profiles of nitrogen fixation $\left(\rho_{\mathrm{N} 2}\right)$ in the $>3 \mu \mathrm{m}$ and nitrogen accumulation $\left(\rho_{\mathrm{acN} 2}\right)$ in the $<3 \mu \mathrm{m}$ size fraction: (a) Cruise Diapalis 4, 'Chenal des Loyautés' location, (b) Diapalis 5 'Baie du Santal' location, (c) Diapalis 6 'Chenal des Loyautés' (solid lines) and 'Baie du Santal' (dashed lines) locations and (d) Diapalis 7 'Baie du Santal' location

They represented, respectively, 84 and $50 \%$ of the total primary production. We noted an exception for some Diapalis 7 stations; these were characterised by a primary production of $50 \%$ carried out by $>10 \mu \mathrm{m}$ organisms. In contrast, the potential photosynthetic carbon assimilation associated with $\mathrm{N}_{2}$ fixation (applying a C:N ratio of 6.6) in the different fractions was very low. It corresponded to $7.7 \pm 8.4$ and $9.5 \pm 15.2 \%$ in the $<10$ and $<3 \mu \mathrm{m}$ size fractions, respectively. In the same way, the primary production associated with diazotrophy in the $>10 \mu \mathrm{m}$ size fraction is very weak, representing $<1.1 \pm 3.8 \%$ of the measured total primary production. Thus, nitrogen fixation sustained a very small part of primary production, indicating that all phytoplankton fractions used other nitrogen forms for growth. F-ratio values generally obtained in such oceanic regions $(0.1$ to 0.2 ), however, indicate that nitrogen fixation may account for $\sim 50 \%$ of new production.
To facilitate comparison with literature data, we calculated mean areal values of diel rates for our experiments (Table 3). We summed day and night rates (expressed as $\mathrm{d}^{-1}$ ) for lagoon samples. But, due to the lack of significant nitrogen fixation during the night (see Fig. 2), we assumed the $12 \mathrm{~h}$ rates to be daily rates at oceanic sites. This assumption could lead to some underestimation of daily integrated rates, if some oceanic diazotroph organisms, not detected in the present experiments, were able to fix nitrogen during the night. It should be noted that only Falcòn et al.'s (2004) data were obtained from experiments of isolated $<10 \mu \mathrm{m}$ organisms, and can be compared to our results of nanoplanktonic nitrogen fixation obtained in the lagoon $\left(\rho_{\mathrm{N} 2}\right)$. All other literature data came from postfractionated samples and, as such, must be considered as $\rho_{\text {acN2}}$, potentially including some trophic transfer of ${ }^{15} \mathrm{~N}$-tracer and not only direct $\mathrm{N}_{2}$ fixation. In the Noumea Lagoon, mean areal rates obtained between 0 and $20 \mathrm{~m}$ depth on the isolated $<10 \mu \mathrm{m}$ fraction were high $\left(214 \mu \mathrm{mol} \mathrm{m} \mathrm{m}^{-2} \mathrm{~d}^{-1}\right)$, representing $91 \%$ of the total daily $(24 \mathrm{~h})$ nitrogen fixation. This value is slightly higher than values given by Falcòn et al. (2004) (62 to $167 \mu \mathrm{mol} \mathrm{m}{ }^{-2} \mathrm{~d}^{-1}$ ). Mean areal $\rho_{\mathrm{N} 2}$ values in the $>10 \mu \mathrm{m}$ size fraction calculated for all Diapalis cruises, ranging between 6 and $474 \mu \mathrm{mol} \mathrm{m}{ }^{-2} \mathrm{~d}^{-1}$, are similar to data obtained in oligotrophic areas for experiments conducted with isolated Trichodesmium. The mean areal $\mathrm{N}_{2}$-fixation rate obtained during Diapalis 7 (474 $\mu \mathrm{mol}$ $\mathrm{m}^{-2} \mathrm{~d}^{-1}$ ), when high densities of Trichodesmium populations were observed, is the maximum rate observed during the experimentation period and is also a higher value than normally measured in oceanic areas. In contrast, the Diapalis 9 cruise (October 2003) is characterised by the absence of Trichodesmium at the sampled locations, and our observations here reveal a very low $\rho_{\mathrm{N} 2}$ in the $>10 \mu \mathrm{m}$ size fraction $\left(6 \mu \mathrm{mol} \mathrm{m} \mathrm{m}^{-2} \mathrm{~d}^{-1}\right)$. This result is surprising when considering the high value of total nitrogen fixation measured at the same time $\left(306 \mu \mathrm{mol} \mathrm{m} \mathrm{m}^{-2} \mathrm{~d}^{-1}\right)$. The nitrogen fixation in the $>10 \mu \mathrm{m}$ size fraction often represented $>50 \%$ of the total fixation (Table 3), but never reached $100 \%$, even when total nitrogen fixation was high, such as during Diapalis 7 (February 2003). Moreover, $\rho_{\mathrm{N} 2}$ in the $>10 \mu \mathrm{m}$ size fraction can account only for a small part of the total nitrogen fixation (2\% during Diapalis 9 and $9 \%$ in the lagoon). During these experiments, Trichodesmium populations were never observed.

\section{DISCUSSION}

The ability to measure high-precision isotope ratios, combined with the sensitive field tracer method (Montoya et al. 1996), permitted the 'direct' diazotrophy 

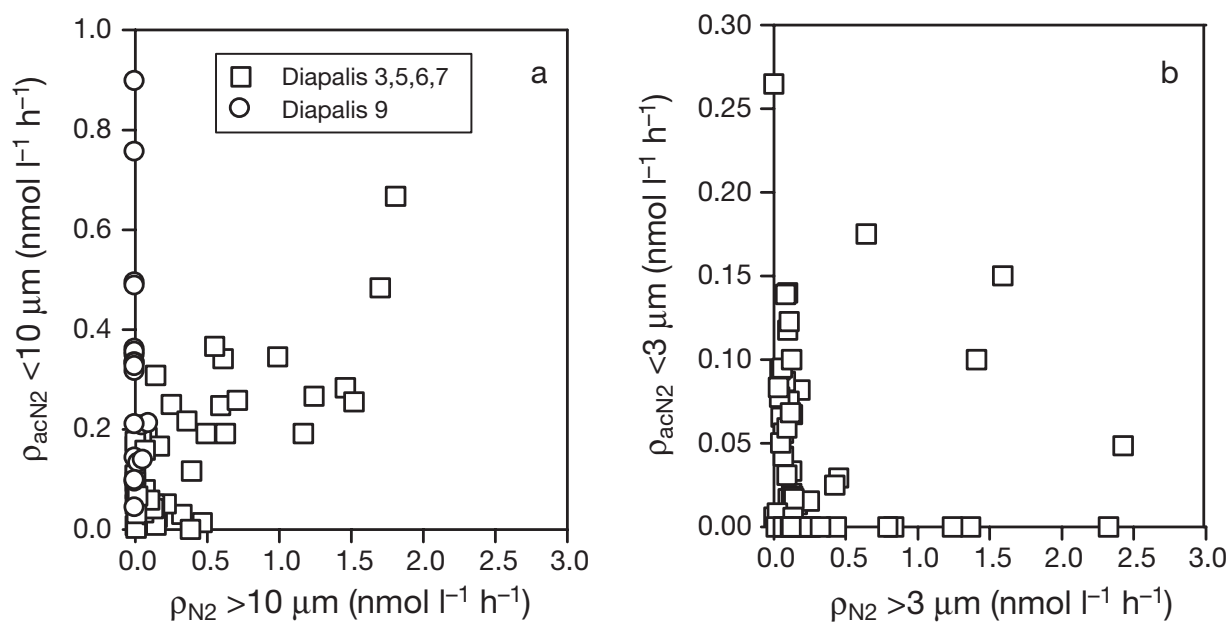

Fig. 6. Comparisons of nitrogen accumulation rates between (a) the $<10$ and $>10 \mu \mathrm{m}$ size fraction and (b) the $<3$ and $>3 \mu \mathrm{m}$ size fraction in the various Diapolis cruises

Table 3. Summary of $\mathrm{N}_{2}$ fixation $\left(\rho_{\mathrm{N} 2}\right)$ and $\mathrm{N}_{2}$ accumulation $\left(\rho_{\mathrm{acN} 2}\right)$ (mean areal rates in $\mu \mathrm{mol} \mathrm{m}^{-2} \mathrm{~d}^{-1}$ ) in different size fractions measured in the present study and from literature data. Values in brackets represent the percent of the GF/F

\begin{tabular}{|c|c|c|c|c|c|c|c|}
\hline \multirow{2}{*}{ Location } & \multirow[t]{2}{*}{ Date } & \multicolumn{3}{|c|}{$-\mathrm{N}$ fixation $\left(\rho_{\mathrm{N} 2}\right)$} & \multicolumn{2}{|c|}{$\mathrm{N}$ accumulation $\left(\rho_{\mathrm{acN} 2}\right)$} & \multirow[t]{2}{*}{ Source } \\
\hline & & $>\mathrm{GF} / \mathrm{F}$ (total) & $>10 \mu \mathrm{m}$ & $<10 \mu \mathrm{m}$ & $<10 \mu \mathrm{m}$ & $<3 \mu \mathrm{m}$ & \\
\hline New Caledonia Diapalis & 4 Apr 2002 & 151 & $111(73 \%)$ & & $40(27 \%)$ & $13(9 \%)$ & Present study \\
\hline New Caledonia Diapalis & 5 May 2002 & 169 & $96(57 \%)$ & & $73(43 \%)$ & $21.5(13 \%)$ & Present study \\
\hline New Caledonia Diapalis & 6 Aug 2002 & 176 & & & & $87(49 \%)$ & Present study \\
\hline New Caledonia Diapalis & 7 Feb 2003 & 703 & $474(67 \%)$ & & $229(33 \%)$ & $52(7 \%)$ & Present study \\
\hline New Caledonia Diapalis & 9 Oct 2003 & 306 & $6(2 \%)$ & & $300(98 \%)$ & & Present study \\
\hline Noumea Lagoon & Oct 2005 & 235 & $21(9 \%)$ & $214(91 \%)$ & & & Present study \\
\hline Tropical N Atlantic $\left(7-12^{\circ} \mathrm{N}\right)$ & $2001-2002$ & & $62-167$ & $37-47$ & & & Falcon et al. (2004) \\
\hline N Pacific (near ALOHA) & 2002 & & 84 & 2.2 & & & Falcon et al. (2004) \\
\hline ALOHA region & $2000-2001$ & & & & 66 & & Montoya et al. (2004) \\
\hline Hawaii region & $2000-2002$ & & & & 24 & & Montoya et al. (2004) \\
\hline Eastern N Pacific gyre & Jul 2002 & & & & 50 & & Montoya et al. (2004) \\
\hline North Australia Coral Sea & Nov 1999 & & & & 126 & & Montoya et al. (2004) \\
\hline Arafura Sea (Australia) & Nov 1999 & & & & 3955 & & Montoya et al. (2004) \\
\hline ALOHA region & $2000-2001$ & & & & $20-35$ & & Dore et al. (2002) \\
\hline ALOHA station & 2000 & & & & 92 & & Zehr et al. (2001) \\
\hline BATS (Bermuda) & 1995-1997 & & 41 & & & & Orcutt et al. (2001) \\
\hline Arabian Sea & May 1995 & & 35-99 (bloom) & & & & Capone et al. (1998) \\
\hline N Atlantic & $1995-2003$ & & 239 & & & & Capone et al. (2005) \\
\hline ALOHA & 1990-1992 & & 84 & & & & Karl et al. (1997) \\
\hline Caribbean Sea & & 161 & & & & & Carpenter \& Price (1977) \\
\hline Southwestern N Atlantic & Nov 1964 & & 41 & & & & Goering et al. (1966) \\
\hline NW Mediterranean Sea & $2003-2004$ & $40-100$ & & & & & Garcia et al. (2006) \\
\hline
\end{tabular}

measurements carried out in the present study; such measurements are very rarely made without concentrated natural seawater or pre-concentrated phytoplankton. Marine waters around New Caledonia seem to be a favourable region for diazotrophy, which can be observed at significant rates throughout the year in both oceanic and lagoonal habitats. The nitrogen fixation rates obtained were high and presented some spatial heterogeneity and high seasonal variability. The reason for this variability is not easy to determine, even though several nutrient conditions have been pointed out as a possible source (Van den Broeck et al. 2004). Results from size fractionation clearly demonstrate that large phytoplankton $(>10 \mu \mathrm{m})$ are not always the predominant pool for accumulation of newly fixed $\mathrm{N}_{2}$, as might be inferred from the preponderance of studies previously conducted on Trichodesmium and diatoms with cyanobacterial endosymbionts.

However, in most of our experiments, post-size-fractionation results do not allow us to distinguish between 
direct nanoplanktonic ${ }^{15} \mathrm{~N}_{2}$ fixation and ${ }^{15} \mathrm{~N}_{2}$ transferred from large diazotrophs to small organisms via recently released organic nitrogen. Glibert \& Bronk (1994) have shown that a high level of $\mathrm{N}_{2}$ fixed (a mean of $50 \%$ ) may be released as dissolved organic nitrogen (DON) by Trichodesmium. The released compounds, even if relatively minimal when compared with ambient seawater concentrations of DON, can be a significant source of new nitrogen for the non-nitrogen-fixing organisms. Indeed, Ohlendieck et al. (2000) showed that ${ }^{15} \mathrm{~N}_{2}$ enrichment measured in the $<3 \mu \mathrm{m}$ size fraction (5 to $10 \%$ of the total ${ }^{15} \mathrm{~N}_{2}$ fixed) is entirely due to assimilation of organic nitrogen recently released by large diazotrophic phytoplankton. Paerl (1984) found a significant amount of ${ }^{15} \mathrm{~N}$ fixed in cultures of Anabaena, which appear to have associated bacteria after a short incubation time. Nevertheless, when Trichodesmium populations were missing (as observed during Diapalis 9), as well as in pre-fractionated samples, the $<10 \mu \mathrm{m}$ organisms were found to be solely responsible for diazotrophic activity, at very high integrated rates (200 to $300 \mu \mathrm{mol} \mathrm{m}{ }^{-2} \mathrm{~d}^{-1}$ ). The range of $<10 \mu \mathrm{m} \mathrm{N} \mathrm{N}_{2}$ fixation values is close to those previously reported in the literature (see Table 3), with the exception of the extremely high rate measured in the Arafura Sea of Australia (Montoya et al. 2004). Rates are equivalent or higher than many values previously given for Trichodesmium. Our study shows that, regardless of the period and of the presence of large diazotrophic populations, nanoplanktonic nitrogen fixation can be a real and significant process (up to $98 \%$ of the total mean areal $\mathrm{N}_{2}$ fixation) in lagoon waters. Since pre-fractionated experiments were not performed during the Diapalis cruises, this result must be confirmed for oceanic waters.

The nanoplanktonic organisms responsible for the high daily and night rates remained unidentified in the present study. Zehr et al. (2001) found small unicellular cyanobacteria (2 to $3 \mu \mathrm{m}$ in diameter) expressing the gene nifH in the subtropical North Pacific; these were associated with significant nitrogen accumulation ( 0.008 to $0.016 \mathrm{nmol}^{-1} \mathrm{~h}^{-1}$ ) in the $<10 \mu \mathrm{m}$ fraction. Mitsui et al. (1986) isolated a marine strain from the benthos that could fix nitrogen in the dark in a chemostat culture. Two larger marine coccoid strains (3 to $4 \mu \mathrm{m}$ in diameter) that fix $\mathrm{N}_{2}$ at night, Cyanothece spp. (Reddy et al. 1993) and Erytthrospera marina (Waterbury et al. 1988), have also been isolated. In the present study, the significant dark fixation obtained from the isolated $<10 \mu \mathrm{m}$ fraction tends to confirm the existence of such small unicellular nocturnal diazotrophs, at least in the Caledonian Lagoon. If all natural nanoplanktonic diazotrophs act like cyanobacteria in cultures, the impact of these organisms on oceanic nitrogen cycling would be even more important.
The large accumulation of ${ }^{15} \mathrm{~N}_{2}$ in the $<3 \mu \mathrm{m}$ size fraction demonstrates a tight coupling between larger diazotrophs and picoplanktonic populations, and shows that newly fixed nitrogen could rapidly provide for the pelagic food web. During all experiments, even if total fixation rates were low, ${ }^{15} \mathrm{~N}_{2}$ accumulation $\left(\rho_{\text {acN2}}\right)$ in picoplankton ranged from 7 to $13 \%$ of the total nitrogen fixation. These percentages are equivalent to those found by Ohlendieck et al. (2000) due to trophic transfer $(5$ to $10 \%)$. Diapalis 6 results show more important nitrogen accumulation in the $<3 \mu \mathrm{m}$ size fraction. The $\rho_{\mathrm{acN} 2}$ integrated rates ranged between 13 and $87 \mu \mathrm{mol}$ $\mathrm{m}^{-2} 12 \mathrm{~h}^{-1}$, which corresponds to $52 \%$ of the total fixed nitrogen. These values are of the same order of magnitude as Zehr et al.'s (2001) data $\left(92 \mu \mathrm{mol} \mathrm{m}^{-2} 12 \mathrm{~h}^{-1}\right)$, calculated from surface nitrogen fixation rates and concentrations of nifH-containing unicellular cyanobacteria over the water column. This observation allows us to pinpoint a previously hypothesised, but still undocumented process, i.e. picoplanktonic nitrogen fixation (Capone 2001, Zehr et al. 2001). Unfortunately, postfractionation experiments did not offer the opportunity to distinguish direct $\mathrm{N}_{2}$ fixation from assimilation of ${ }^{15} \mathrm{~N}$-labeled organic compounds by heterotrophic picoplankton. Nevertheless, these experiments highlight new information regarding the accumulation of recently fixed nitrogen in picoplankton and its trophic transfer through the microbial food web. This finding poses a serious challenge to our understanding of the nitrogen cycle. Thus, the microbial loop, generally considered to be driven only by nitrogen regeneration, could also be an important way for new nitrogen to enter the system, either by short-term trophic transfer from large cyanobacteria to small heterotroph organisms or by direct nitrogen fixation by nanoplanktonic cyanobacteria. However, this last process needs to be confirmed through future studies which should take into account all size populations (and not only Trichodesmium), in order to correctly quantify diazotrophy rates in pelagic waters and identify the associated organisms. It will then be essential to focus on size-fractionation experiments with pre-filtered seawater coupled with organism examination using microscopy and molecular techniques. Moreover, the considerable temporal and local variations in nitrogen fixation found in the present work indicate that broader studies in time and location are needed to assess the contribution of $\mathrm{N}_{2}$ fixation in different size classes to the nitrogen budget in this region of the Pacific Ocean.

Acknowledgements. The authors thank A. Le Bouteiller, the DIAPAZON coordinator, and L. Charpy, the Noumea Lagoon experiment coordinator, and all the IRD staff in Noumea. They also gratefully acknowledge L. Armand for her linguistic and scientific advice. In addition, the captain and crew of 
RV 'Alis' are thanked for shipboard support operations at sea. This work was supported by IRD, INSU, PROOF (PROcessus biogéochimiques dans l'Océan et Flux).

\section{LITERATURE CITED}

Capone DG (2001) Marine nitrogen fixation: What's the fuss? Curr Opin Microbiol 4:341-348

Capone DG, Zehr JP, Pearl HW, Bergman B, Carpenter EJ (1997) Trichodesmium: a globally significant marine cyanobacterium. Science 276:1221-1229

Capone DG, Subramaniam A, Montoya JP, Voss M, Humborg C, Johansen A, Siefert R, Carpenter EJ (1998) An extensive bloom of the $\mathrm{N}_{2}$-fixing cyanobacterium, Trichodesmium erythraeum, in the Central Arabian Sea. Mar Ecol Prog Ser 172:281-292

Capone DG, Burns JA, Montoya JP, Subramniam A, Mahaffey C, Gunderson T, Michaels AF, Carpenter EJ (2005) Nitrogen fixation by Trichodesmium spp.: an important source of new nitrogen to the tropical and subtropical North Atlantic Ocean. Global Biogeochem Cycles 19:1-17

Carpenter EJ, Price CC (1977) Nitrogen fixation, distribution, and production of Oscillatoria (Trichodesmium) in the northwestern Atlantic Ocean and Caribbean Sea. Limnol Oceanogr 22:60-72

Dore JE, Brum JR, Tupas LM, Karl DM (2002) Seasonal and interannual variability in the sources of nitrogen supporting export in the oligotrophic subtropical North Pacific Ocean. Limnol Oceanogr 47:1595-1607

Dugdale RC, Wilkerson FP (1986) The use of ${ }^{15} \mathrm{~N}$ to measure nitrogen uptake in eutrophic oceans, experimental considerations. Limnol Oceanogr 31:673-689

Falcòn LI, Carpenter EJ, Cipriano F, Bergman B, Capone DG (2004) $\mathrm{N}_{2}$ fixation by unicellular bacterioplankton from the Atlantic and Pacific Oceans: phylogeny and in situ rates. Appl Environ Microbiol 70:765-770

Garcia N, Raimbault P, Gouze E, Sandroni V (2006) Nitrogen fixation and primary production in western Mediterranean. CR Biol 329:742-750

Glibert PM, Bronk DA (1994) Release of dissolved organic nitrogen by marine diazotrophic cyanobacteria, Trichodesmium spp. Appl Environ Microbiol 60:3996-4000

Goering JJ, Dugdale RC, Menzel DW (1966) Estimate of in situ rates of nitrogen uptake by Trichodesmium sp. in the tropical Atlantic Ocean. Limnol Oceanogr 11:614-620

Karl D, Letelier R, Tupas L, Dore J, Christian J, Hebel D (1997) The role of nitrogen fixation in biogeochimical cycling in the subtropical North Pacific Ocean. Nature 386:533-538

Lipschultz F, Owens NJP (1996) An assessment of nitrogen fixation as a source of nitrogen to the North Atlantic Ocean. Biogeochemistry 35:261-274

Malone TC (1980) Algal size. In: Morris I (ed) The physiological ecology of phytoplankton. University of California Press, Berkeley, p 433-463

Editorial responsibility: Fereidoun Rassoulzadegan (Contributing Editor), Villefranche-sur-Mer, France
Mitsui A, Kumazawa S, Takahashi A, Ikemoto H, Cao S, Arai $\mathrm{T}$ (1986) Strategy by which nitrogen-fixing cyanobacteria grows photoautotrophically. Nature 323:720-722

Montoya JP, Voss M, Kähler P, Capone DG (1996) A simple, high-precision, high-sensitivity tracer assay for $\mathrm{N}_{2}$ fixation. Appl Environ Microbiol 62(3):986-993

Montoya JP, Holl CM, Zehr JP, Hansen A, Villareal TA, Capone DG (2004) High rates of $\mathrm{N}_{2}$ fixation by unicellular diazotrophs in the oligotrophic Pacific Ocean. Nature 430: 1027-1031

Mulholland MR, Capone DG (2000) The nitrogen physiology of the marine $\mathrm{N}_{2}$-fixing cyanobacteria Trichodesmium spp. Trends Plant Sci 5:148-153

Ohlendieck U, Stuhr A, Siegmund H (2000) Nitrogen fixation by diazotrophic cyanobacteria in the Baltic Sea and transfer of newly fixed nitrogen to picoplankton organisms. J Mar Syst 25:213-219

Orcutt KM, Lipschultz F, Gundersen K, Arimoto R, Michaels AF, Knap AH, Gallon JR (2001) A seasonal study of the significance of $\mathrm{N}_{2}$ fixation by Trichodesmium spp. at the Bermuda Atlantic time-series study (BATS) site. Deep-Sea Res II 48:1583-1608

Paerl HW (1984) Transfer of $\mathrm{N}_{2}$ and $\mathrm{CO}_{2}$ fixation products from Anabaena oscillarioides to associated bacteria during inorganic carbon sufficiency and deficiency. J Phycol 20:600-608

Paerl HW (1990) Physiological ecology and regulation of $\mathrm{N}_{2}$ fixation in natural waters. Adv Microb Ecol 11: 305-344

Reddy KJ, Haskell JB, Sherman DM, Sherman LA (1993) Unicellular, aerobic nitrogen-fixing cyanobacteria of the genus Cyanothece. J Bacteriol 175:1284-1292

Slawyk G, Collos Y (1984) ${ }^{13} \mathrm{C}$ and ${ }^{15} \mathrm{~N}$ uptake by marine phytoplankton. III. Interactions in euphotic zone profiles of stratified oceanic areas. Mar Ecol Prog Ser 19:223-231

Stockner JG, Antia NJ (1986) Algal picoplankton from marine and freshwater ecosystems: a multidisciplinary perspective. Can J Fish Aquat Sci 43:2472-2503

Van den Broeck N, Moutin T, Rodier M, Lebouteiller A (2004) Seasonal variations of phosphate availability in the SW Pacific Ocean near New Caledonia. Mar Ecol Prog Ser 268:1-12

Waterbury JB, Watson SW, Valois FW (1988) Temporal separation of photosynthesis and dinitrogen fixation in the marine unicellular cyanobacterium Erythrosphaera marina. EOS Trans Am Geophys Union 69:1089

Weiss RF (1970) The solubility of nitrogen, oxygen and argon in water and seawater. Deep-Sea Res I 17:721-735

Zehr JP, Capone DG (1996) Problems and promises of assaying the genetic potential for nitrogen fixation in the marine environment. Microb Ecol 32:263-281

Zehr JP, Waterbury JB, Turner PJ, Montoya JP, Omoregie E, Steward GF, Hansen A, Karl DM (2001) Unicellular cyanobacteria fix $\mathrm{N}_{2}$ in the subtropical North Pacific Ocean. Nature 412:635-638

Submitted: September 28, 2006; Accepted: January 15, 2007 Proofs received from author(s): July 5, 2007 